\title{
Microbiological and Physicochemical Properties of Mayonnaise Using Biopolymer of Whey Protein-Gelatin-Chitosan during Storage
}

\author{
Novia Wahyuana Triawati ${ }^{1}$, Lilik Eka Radiati ${ }^{2}$, Imam Thohari ${ }^{2}$ and Abdul Manab ${ }^{2 *}$ \\ ${ }^{1}$ Student of Animal Product Technology Department, Animal Husbandry Faculty, Brawijaya \\ University, Malang, East Java, Indonesia \\ ${ }^{2}$ Animal Product Technology Department, Animal Husbandry Faculty, Brawijaya University, \\ Malang, East Java, Indonesia \\ *Corresponding author email id:
}

\section{A B S T R A C T}

Keywords

$\mathrm{pH}$, emulsion stability, emulsion activity, viscosity, microscopic, particle size, and total microorganism.

Article Info

Accepted:

12 June 2016

Available Online:

10 July 2016
The aim of this research was to know the effect of Whey protein-gelatinchitosan biopolymer and storage time on microbiologycal and physicochemical properties of mayonnaise. The treatment was biopolymer content $(0,1 \%, 2 \%$ and $3 \%(\mathrm{w} / \mathrm{v}))$ and storage time $(0,2,4$ and 6 weeks). The results showed that the addition of biopolymer gave highly significant effect $(\mathrm{P}<0.01)$ on emulsion stability, emulsion activity, viscosity, particle size and total microbia, however didn't gave significant effect $(\mathrm{P}>0.05)$ on mayonnaise $\mathrm{pH}$. The microscopics showed that biopolymer capable to decreased oil droplet size, however there are enlargement oil droplet during storage. It concluded that biopolymer of whey protein-gelatin-chitosan stabilize microbiologycal and physicochemical properties of mayonnaise during 4 weeks storage.

\section{Introduction}

Biopolymer is a natural polymer which produced using natural polymer monomers, it can be obtained from plants and animals. Biopolymer origin animals are gelatin, whey protein and chitosan. According to Cho et al., (2004), gelatin is one of natural biopolymer derivative protein and derived from collagen which denatured as a result of thermo hydrolysis. Sobral and Habitante (2001) explained that gelatin obtained by means the hydrolysis of collagen and it soluble in water. The use of gelatin in food products is as a stabilizer, in the form of gel, a fastener, a thickener and emulsifier (Hernandez et al., 2009).

Whey protein according to Korhonen (2009) is a globular protein cluster of hydrophobic and sulphhydril. Biopolymer of gelatin and whey protein mixed through a crosslink process using plants polyphenol containing chatecin. Chatecin is one of the chemical content which is found in plants. The chemical content is readily soluble in water. 
Hernandez-balada et al., (2009) explained that the purpose of crosslink addition is stabilization an emulsion and increase viscosity. Previous research conducted by Liang and $\mathrm{Xu}$ (2001), that tea catechin capable to stabilize cream because catechin may be act as a crosslink agent. According to Wu et al., (2013), that catechin have ability through interaction with milk protein. Rahayu et al., (2015) noted that whey protein and gelatin crosslinked is capable to raising molecular weights of whey protein and gelatin. Li et al., (2009) explained that crosslink method can be shown with an increase in molecules weight of a biopolymer.

Whey protein and gelatin crosslinked biopolymer need to be added with chitosan to increase biopolymer properties. Chitosan is a natural product obtained from shrimp exosceletons. Chitosan processed using alkaline deacetilation and potential as a preservative of certain kinds of food (Rhoades and Roller, 2000). Characteristic of chitosan as described by Tamura et al. (2002), that the more acetyl group is missing from the polymer chitin, the more strong interactions between ion and hydrogen bonds and peroxide. Chitosan potential as an antibacterial agent because of an enzyme lysosyme aminopolysachcharide act as delayed microbes growth (Cruz et al., 2012), and as a forming good texture (Tang et al., 2007).

Mayonnaise is food products which have low emulsion stability during storage. Mayonnaise is a vegetable oils emulsion in an acid that stabilized by lecithin, egg yolk lipoprotein that acts as an emulsifier agent (Gaonkar et al., 2010). Mayonnaise emulsion is stable with egg yolk addition as an emulsifier, because lecithin which contained in egg yolk act as emulsifier (Davis and Reeves, 2002). Instability an emulsion resulting in the separation oil and vinegar caused increasing microbes growth of food products (Morhsed, 2011).

The benefit of mixing crosslinked gelatinwhey protein biopolymer with chitosan as emulsifier and antimicrobial agent, the biopolymers to be added to mayonnaise for maintaining emulsion stability and inhibit microbial growth of mayonnaise during storage.

\section{Materials and Methods}

\section{Material}

Gelatin (Gelita NZLTD), Whey protein isolated (Musclefeastindo), Chitosan. $\mathrm{NaN}_{3}$ (Merck) (to retard spoilage), sodium carbonate, soy bean oil, sodium dedocyl sulfate (Merck), buffer $\mathrm{pH} 4$ and $\mathrm{pH} \mathrm{7,}$ acetic acid (Merck), bromphenol blue (Merck), rhodamin, PCA (Oxoid), pepton (Oxoid). The tool used were spectrophotometer, $\mathrm{pH}$ meters, Particle Size Analyser (PSA), autoclave, waterbath, incubator, microscope fluorescence, viscometer, test tube.

\section{Methods}

\section{Formulated mayonnaise}

Formulated mayonnaise shown at Table 1.

\section{Mayonnaise manufacturing (Thaiudom and Kallaya, 2011)}

1. Yolks, sugar, salt and water shaken with a mixer at $1150 \mathrm{rpm}$ speed for 5 minutes

2. Add vinegar and mix using mixer at $400 \mathrm{rpm}$ speed for 5 minutes

3. Mixed biopolymer with soy bean oil on a mixer at $1150 \mathrm{rpm}$ speed for 4-5 minutes 
4. Step 2 and 3 mixed with a mixer at $1150 \mathrm{rpm}$ speed for $1-5$ minutes

5. Finnaly, added soy bean oils slowly and done mixing with a mixer on 1150-1750 rpm speed for 10 minutes

\section{Preparation of biopolymer of crosslinked gelatin-whey protein and chitosan}

Add $1 \mathrm{~g}$ chitosan on solution containing 10 $\mathrm{ml}$ acetic acid and $30 \mathrm{ml}$ aquadest, stirred at temperature $50^{\circ} \mathrm{C}$ until homogen. Add chitosan solution to biopolymer of crosslinked gelatin and whey protein crosslink with concentration 10:15 (b/v) at temperature $50^{\circ} \mathrm{C}$. The mixture storage for $24 \mathrm{~h}$ at room temperature, furthermore at at $4^{\circ} \mathrm{C}$ for $24 \mathrm{~h}$ and returned to room temperature (Thaiudom and Kallaya, 2011).

\section{Emulsion stability and emulsion activity measurement}

Emulsion stability index (ESI) defined as the ability of a product to maintain the quality, strength and purity products (El-Kheir $\mathrm{et}$ al., 2008). Emulsion stability is a capacity to sustain physical properties or emulsion the material. Emulsion activity index (EAI) was determined as describe by Zheng and Jiang (2014) with a slight modification and emulsion stability index (ESI). The procedure of emulsion stability index (ESI) was sample mixed with soy bean oils at 1 min, then it was mixed thoroughly for $10 \mathrm{~s}$ using a vortex mixer with $0.1 \%$ SDS diluted 100 -fold. After that emulsion were wait at 10 minutes. The resulting dispersion was measured using spectrophotometer (ElKheir et al., 2008).

$$
\operatorname{ESI}(\%)=\mathrm{A}_{10} / \mathrm{A}_{0} \times 100
$$

Where: $\mathrm{A}_{0}=\mathrm{A}_{500}$ at time of 0 minutes, $A_{10}=A_{500}$ at time of 10 minutes EAI $\left(\mathrm{m}^{2} / \mathrm{g}\right)=(2 \times 2.303 \times \mathrm{A} \times \mathrm{DF}) /$
I x C

Where; $\mathrm{A}=\mathrm{A}_{500}, \mathrm{DF}=$ dilute factor (100), $\mathrm{I}$ $=$ path length of cuvette $(\mathrm{m}), \mathrm{x}=$ oil volume fraction, $\mathrm{C}=$ sample concentration

\section{Viscosity measurement}

$100 \mathrm{ml}$ of mayonnaise placed in to container sample. Immerse the spindle designated in the product specification into the sample to the groove on the spindle shaft. Do not allow air bubbles to be formed. Attach the spindle to the viscometer. The spindle should not touch the bottom or sides of the container and should be centered. Reconfirm that the viscometer is level (Aluko and McIntosh, 2005).

\section{Microscopic observation}

Microscopic observation using fluorescent microscope to observe the mayonnaise structure. Add $0.015 \mathrm{~g}$ rhodamin B on $10 \mathrm{ml}$ aquadest stirred until homogeneous. Stain 5 g mayonnaise using $100 \mu \mathrm{L}$ rhodamin $\mathrm{B}$. to test tube until homogeneous (Strauss and Gibson, 2004).

\section{Determination of Microbes}

Enumeration of microbes in mayonnaise using pour plate method as total plate count (TPC). Mayonnaise with a serial dilution in sterilized pepton water $(0.1 \%)$ poured into plates, and allowed PCA to solidify. The plates are then incubated at $37^{\circ} \mathrm{C}$ for $24 \mathrm{~h}$, to permit microbial reproduction so that colonies develop that can be seen without the aid of a microscope. It is assumed that each bacterial colony arises from an individual cell that has undergone cell division. Therefore, by counting the number of colonies and accounting for the dilution factor, the number of bacteria in the original sample can be determined (Fardiaz, 1993): 
colony per $\mathrm{ml}=\sum$ colony per plate (1/fp)

where: $\sum$ colony per plate : total of colony per plate

$$
\mathrm{fp} \quad \text { : dilution }
$$

\section{Particle Size Distribution measurement}

Drop size distribution was determined by the Horiba LA 500 (Horiba Instrument, Irvine CA) laser diffraction particle size distribution analyzer, $5 \mathrm{~g}$ sample added 15 $\mathrm{ml}$ aquadest then mixed so homogeneous. The result of the analysis is a volume weight distribution over the size limits of the optical configuration used. The measurement using Particle Size Analyzer (PSA), that the principle of PSA using dynamic light scattering (DLS) (Gaonkar et al., 2010).

\section{pH Measurement}

Suwetja (2007) explained that the measurement of $\mathrm{pH}$ using $\mathrm{pH}$ meters. $10 \mathrm{~g}$ sample mixed with $20 \mathrm{ml}$ aquadest during 1 minute, then measured $\mathrm{pH}$ using $\mathrm{pH}$ meters

\section{Result and Discussion}

\section{Emulsion Stability}

Whey protein-gelatin-chitosan biopolymer and storage time gave highly significant effect $(\mathrm{P}<0.01)$ on emulsion stability of mayonnaise.as shown at Table 2. Biopolymer addition at $1 \%$ and control decreased emulsion stability sharply during storage from 81.94 to 33.70 and 71.87 to 23.50 respectively, decreased gradually at $2 \%$ treatment from 91.94 to 56.89 and stabilize enough at $3 \%$ treatment from 98.91 to 71.42 .

Higher emulsion stability of mayonnaise may be due to interaction between biopolymer component with fat or oil in mayonnaise. Whey protein and gelatin crosslinked may be more adsorbed on the surface of mayonnaise oil droplets, both of protein are emulsion forming and stabilizing agent, whereas chitosan as a polysaccharide used as thickening and water holding agents (Dickinson, 1992).

Polysaccharides have capacity to bind and immobilize a large amount of water stabilizing the emulsion (Koocheki, Kadkhodaee, Mortazavi, Shahidi, \& Taherian, 2009) and reduce repulsion force between oil droplet thus affect the stability of an emulsion.

Lower emulsion stability of mayonnaise during storage may be due to decreasing of mayonnaise $\mathrm{pH}$, acidification of aqueous phase of mayonnaise caused destabilization of electrostatic interaction between protein thereby decreasing the emulsion stability of mayonnaise.

\section{Emulsion activity}

Whey protein-gelatin-chitosan biopolymer and storage time gave highly significant effect $(\mathrm{P}<0.01)$ on emulsion activity of mayonnaise as shown at Table 2 . Biopolymer stabilize emulsion activity during storage, however the biopolymer treatment at $3 \%$ gave higher emulsion activity of mayonnaise. Emulsion activity of mayonnaise using biopolymer at $0 \%, 1 \%$, $2 \%$ and $3 \%$ gave emulsion activity 72.95 , $75.65,78.63,82.62 \mathrm{~m}^{2} / \mathrm{g}$ respectively

The enhancement of emulsion activity may be act the crosslinked biopolymer as an emulsifier, according to Rahayu et al (2015), that whey protein and gelatin crosslinked capable to increasing emulsion activity. The higher concentration of biopolymer, the higher emulsion activity of mayonnaise 


\section{Viscosity}

Whey protein-gelatin-chitosan biopolymer and storage time gave highly significant effect $(\mathrm{P}<0.01)$ on viscosity of mayonnaise as shown at Table 2. Biopolymer addition gave higher viscosity of mayonnaise than control, higher biopolymer gave higher viscosity of mayonnaise.

Biopolymer addition increased mayonnaise viscosity, however mayonnaise viscosity decreased during storage for all treatment. Increasing viscosity due to whey protein and gelatin crosslinked and chitosan contained in biopolymer have high capacity to bind free water and act as a stabilizer caused inhibition of continuous phase mobility.

Decreasing mayonnaise viscosity during storage attributed with decreasing mayonnaise $\mathrm{pH}$, longer storage caused decreasing $\mathrm{pH}$. Decreasing $\mathrm{pH}$ caused lowering water binding capacity of protein contained within biopolymer, at lower $\mathrm{pH}$ protein neutralized by acid and aggregate formed. Aggregate forming as an indicator increasing intermolecular interaction between protein, and decreasing water binding of protein. Decreasing viscosity during storage may be due to mayonnaise structure as shown at Fig 1. Prolonging mayonnaise storage produced higher oil droplet, this result may be attributed with lowering emulsion stability during storage.

\section{pH}

Whey protein-gelatin-chitosan biopolymer and storage time didn't gave significant effect $(\mathrm{P}>0.05)$ on mayonnaise $\mathrm{pH}$ as shown at Table 2, however biopolymer addition decreased gradually mayonnaise $\mathrm{pH}$ during storage. Decreasing mayonnaise $\mathrm{pH}$ attributed with microbial growth during storage, increasing microbial growth in mayonnaise produced more organic acid. Higher organic acid content in mayonnaise decreased mayonnaise $\mathrm{pH}$, decreasing $\mathrm{pH}$ caused some physical properties changes of mayonnaise.

\section{Microscopics}

Figure.1 shown the microstructure of mayonnaise with biopolymer addition during storage. Fig 1 showed that biopolymer addition produced small oil droplet than control, the more biopolymer addition, the more small oil droplet formed in mayonnaise. Storage time affect oil droplet size, prolonging storage time of mayonnaise produced bigger oil droplet.

Smaller oil droplet of mayonnaise that using biopolymer indicated that whey protein and gelatin crosslinked in biopolymer act as emulsifier agent, both of the protein may be absorbed on the surface of oil droplet caused increasing opposite force between oil droplet and decreasing surface tension of oil droplet in mayonnaise. Chitosan in biopolymer more act as stabilizer the emulsion that formed by whey protein and gelatin. Chitosan have high capacity to bind water surrounded oil droplet, this result caused viscosity increasing.

Increasing oil droplet size in mayonnaise during storage may be due to decreasing emulsion stability. Microbial growth of mayonnaise during storage increased, this result caused decreasing mayonnaise $\mathrm{pH}$ due to organic acid produced by microba.

Decreasing $\mathrm{pH}$ of mayonnaise caused decreasing capability of biopolymer on emulsion stability, because at lower $\mathrm{pH}$ caused aggregate forming of whey protein and gelatin. 
Int.J.Curr.Microbiol.App.Sci (2016) 5(7): 191-199

Table.1 Formulation of mayonnaise

\begin{tabular}{lcccc}
\hline Materials $(\%)$ & P0 & P1 & P2 & P3 \\
\hline Soy bean oil & 81,82 & 81,82 & 81,82 & 81,82 \\
Yolk & 5,46 & 5,46 & 5,46 & 5,46 \\
Apple vinegar & 5,46 & 5,46 & 5,46 & 5,46 \\
Water & 5,46 & 4,46 & 4.26 & 3,26 \\
Sugar & 0,9 & 0,9 & 0,9 & 0,9 \\
Salt & 0,9 & 0,9 & 0,9 & 0,9 \\
Biopolymer & 0 & 1 & 2 & 3 \\
\hline
\end{tabular}

Table.2 Physical properties of mayonnaise

\begin{tabular}{|c|c|c|c|c|c|c|c|c|c|c|c|c|c|c|c|c|}
\hline Biopolyme & \multicolumn{4}{|c|}{ 0 (control) } & \multicolumn{4}{|c|}{1} & \multicolumn{4}{|c|}{2} & \multicolumn{4}{|c|}{3} \\
\hline $\begin{array}{l}\begin{array}{l}\text { Storage } \\
\text { (weeks) }\end{array} \\
\end{array}$ & $\mathbf{0}$ & 2 & 4 & 6 & $\mathbf{0}$ & 2 & 4 & 6 & $\mathbf{0}$ & 2 & 4 & 6 & $\mathbf{0}$ & 2 & 4 & 6 \\
\hline $\begin{array}{c}\text { Emulsion } \\
\text { stability }\end{array}$ & $\begin{array}{c}71.8 \\
7\end{array}$ & $\begin{array}{c}51.5 \\
9\end{array}$ & $\begin{array}{c}33.7 \\
1\end{array}$ & $\begin{array}{c}23.5 \\
0\end{array}$ & $\begin{array}{c}81.9 \\
4\end{array}$ & $\begin{array}{c}62.7 \\
7\end{array}$ & $\begin{array}{c}44.5 \\
2\end{array}$ & $\begin{array}{c}33.7 \\
0\end{array}$ & $\begin{array}{c}91.9 \\
4\end{array}$ & $\begin{array}{c}81.1 \\
9\end{array}$ & $\begin{array}{c}71.6 \\
4\end{array}$ & 56.89 & $\begin{array}{c}98.9 \\
1\end{array}$ & $\begin{array}{c}81.4 \\
5\end{array}$ & $\begin{array}{c}80.4 \\
5\end{array}$ & $\begin{array}{c}71.4 \\
2\end{array}$ \\
\hline $\begin{array}{c}\text { Emulsion } \\
\text { activity }\end{array}$ & $\begin{array}{c}72.9 \\
5\end{array}$ & $\begin{array}{c}72.5 \\
2\end{array}$ & $\begin{array}{c}78.8 \\
0\end{array}$ & $\begin{array}{c}81.6 \\
1\end{array}$ & $\begin{array}{c}75.6 \\
5\end{array}$ & $\begin{array}{c}75.7 \\
3\end{array}$ & $\begin{array}{c}81.4 \\
2\end{array}$ & $\begin{array}{c}82.6 \\
3\end{array}$ & $\begin{array}{c}78.6 \\
3\end{array}$ & $\begin{array}{c}89.5 \\
7\end{array}$ & $\begin{array}{c}90.9 \\
1\end{array}$ & 93.54 & $\begin{array}{c}82.6 \\
2\end{array}$ & $\begin{array}{c}93.9 \\
4\end{array}$ & $\begin{array}{c}94.5 \\
6\end{array}$ & $\begin{array}{c}96.3 \\
1\end{array}$ \\
\hline Viscosity & $\begin{array}{c}48.4 \\
0\end{array}$ & $\begin{array}{c}41.5 \\
3\end{array}$ & $\begin{array}{c}27.4 \\
3\end{array}$ & $\begin{array}{c}13.9 \\
7\end{array}$ & $\begin{array}{c}61.8 \\
3\end{array}$ & $\begin{array}{c}42.8 \\
7\end{array}$ & $\begin{array}{c}31.9 \\
5\end{array}$ & $\begin{array}{c}20.1 \\
7\end{array}$ & $\begin{array}{c}70.6 \\
0\end{array}$ & $\begin{array}{c}45.3 \\
7\end{array}$ & $\begin{array}{c}41.3 \\
3\end{array}$ & 31.17 & $\begin{array}{c}80.0 \\
0\end{array}$ & $\begin{array}{c}48.5 \\
7\end{array}$ & $\begin{array}{c}45.8 \\
3\end{array}$ & $\begin{array}{c}42.7 \\
3\end{array}$ \\
\hline $\mathrm{pH}$ & 5.1 & 4.8 & 4.7 & 4.3 & 5.3 & 5.0 & 4.6 & 4.2 & 5.2 & 5.0 & 4.8 & 4.2 & 5.2 & 5.0 & 4.7 & 4.3 \\
\hline
\end{tabular}

Table.3 Particles size of mayonnaise

\begin{tabular}{ccccc}
\hline Storage (weeks) & 0 & 2 & 4 & 6 \\
\cline { 1 - 2 } Biopolymer $(\%)$ & & & & \\
\hline 0 & 106.40 & 110.06 & 112.58 & 115.29 \\
1 & 95.82 & 108.09 & 109.58 & 110.53 \\
2 & 82.90 & 83.36 & 100.16 & 102.72 \\
3 & 38.66 & 68.45 & 92.11 & 95.82 \\
\hline
\end{tabular}

Table.4 Total microbe of mayonnaise during storage (log CFU/ml/g)

\begin{tabular}{|c|c|c|c|c|}
\hline Storage (weeks) & 0 & 2 & 4 & 6 \\
\hline Biopolymer (\%) & & & & \\
\hline 0 & 3.64 & 5.82 & 6.63 & 7.47 \\
\hline 1 & 2.92 & 4.93 & 5.24 & 6.15 \\
\hline 2 & 2.26 & 4.34 & 5.10 & 6.66 \\
\hline 3 & 2.21 & 2.25 & 2.46 & 5.58 \\
\hline
\end{tabular}


Fig.1 Microscopic of mayonnaise contained biopolymer during storage.
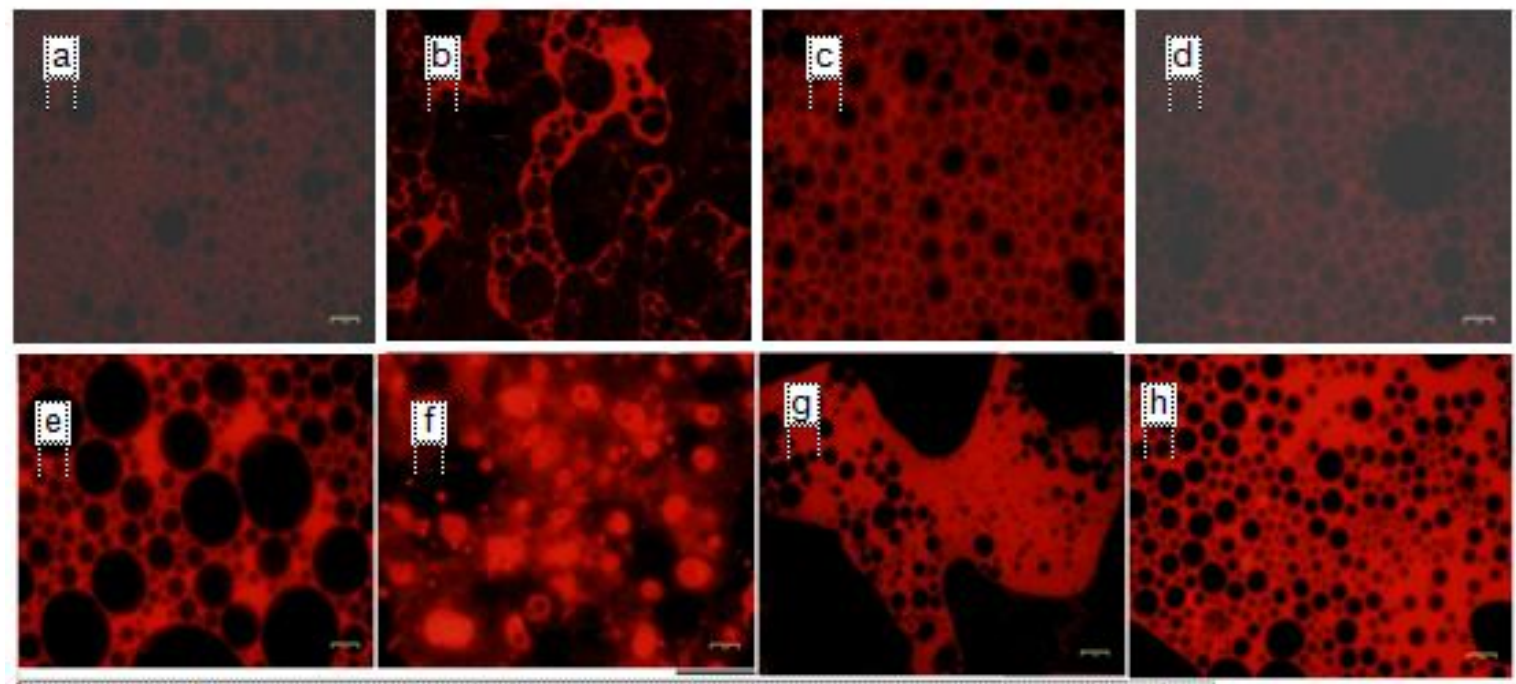

a.Fresh mayonnaise (control)

b.Fresh mayonnaise, $1 \%$ biopolymer

c.Fresh mayonnaise, $2 \%$ biopolymer

d.Fresh mayonnaise, $3 \%$ biopolymer

e.Storage mayonnaise, (control)

f.Storage mayonnaise, $1 \%$ biopolymer

g.Storage mayonnaise, $2 \%$ biopolymer

h.Storage mayonnaise, $3 \%$ biopolymer

Fig.2 Particle size of mayonnaise
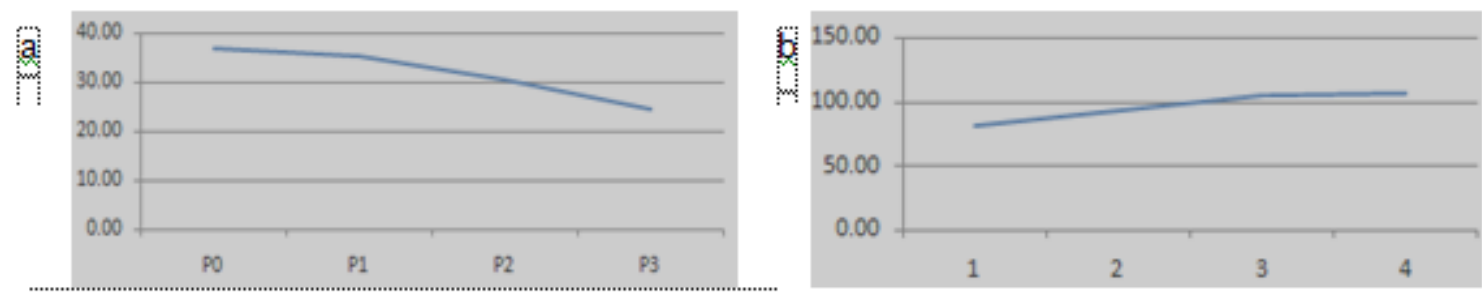

\section{Particles size}

The result of analysis of varian showed that biopolymer addition and storage time gave highly significant effect $(\mathrm{P}<0.01)$ on particles size of mayonnaise as shown at Table 3 and Fig 2. Biopolymer of whey protein and gelatin crosslink and chitosan act as emulsifier and stabilizer agent in mayonnaise, the higher addition of biopolymer, the smaller particle size of mayonnaise. This result indicated that there are some intensive interaction between biopolymer and mayonnaise component. These interactions prevent enlargement aggregate and ion droplet forming in mayonnaise. However, Its ability to maintain small aggregate during storage was decreased. This result may be attributed with $\mathrm{pH}$ changes and increasing microbial growth during storage of mayonnaise. Decreasing $\mathrm{pH}$ caused decreasing ability of biopolymer to prevent enlargement of mayonnaise particle size during storage. 


\section{Total microbe}

The result of analysis ANOVA showed that biopolymer addition and storage time gave highly significant effect $(\mathrm{P}<0.01)$ on total of microbe in mayonnaise as shown at Table 4. The higher biopolymer addition, the higher antimicrobial activity of biopolymer to retard microbial growth during storage of mayonnaise, prolonging storage of mayonnaise increased microbial growth of mayonnaise.

Antimicrobial activity of the biopolymer attributed with antimicrobial properties of chitosan, it is a positive charge polycationic that capable to inhibit bacteria and mold growth (Chaiyakosha et al., 2007), positive charge of amino acid in chitosan capable to interacted with negative charge at microbial cell membrane caused destroying lipoprotein layer and intracellular material, chitosan as oligomer capable to penetrate in intracellular to inhibit transformation from DNA to RNA and inhibition nutrient transport via cell wall protection (Killay, 2013; Pereda, 2011).

It concluded that biopolymer of whey protein-gelatin-chitosan capable to stabilize emulsion stability and emulsion index, increased viscosity, decreased particle size, oil droplet size and microbial growth in mayonnaise during storage. Biopolymer addition at 3\% gave better physical and microbial properties of mayonnaise.

\section{References}

Aluko, R.E., T. McIntosh. 2005. Limited enzymatic proteolysis the level of incorporation of canola proteins into mayonnaise. Innovative Food Sci. Emerg. Technol., 6: 195-202.

Chaiyakosha, S., W. Charernjirtragul, K. Umsakul and V. Vuddhakul. 2007. Comparing the Efficiency Of Chitosan With Chlorine For Reducing Vibrio
Parahaemolyticus In Shrimp. Food Control, 18: 1031-1035.

Cho, S.M, K.S. Kwak, D.C. Park, Y.S. Gu, C.I. Ji, D.H. Jang, Y.B. Lee and S.B. Kim. 2004. Processing Optimization and Functional Properties of Gelatin from Shark (Isurus oxyrinchus) Cartilage. Food Hydrocolloids, 18: 573579.

Cruz, S.H., G.A.G. Pereira and S.A. Romero. 2012. Purification, Characterization and Structural Determination of Chitinase Produced by Moniliopthora perniciosa. Annals of Brazilian Acad. Sci., 84(2) : 469-486.

Davis, C., Reeves. 2002. High value opportunities from the chicken egg. A report for Rural Industries Research and Development Corporation. RIRDC Publication 02 (094): 61.

Dickinson, E. 1992. Hydrocolloids at interfaces and the influence on the properties of dispersed systems. Food Hydrocolloids, 17: 25-39.

El-Kheir, M.K.S., A.E.G. Yagoub and A.A.A. Baker. 2008. Emulsion-Stabilizing Effect of Gum from Acacia senegal (L) Willd. The Role of Quality and Grade of Gum, Oil Type, Temperature, Stirring Time and Concentration, Pakistan J. Nutri., 7: 395-399.

Fardiaz, Srikandi. 1993. Analysis Microbiology Fod. Jakarta : PT.Raja Grafindo Persada

Gaonkar, G.R. Koka, K. Chen and B. Campbell. 2010. Emulsifying functionality of enzyme modified milk proteins in $\mathrm{O} / \mathrm{W}$ and mayonnaise-like emulsions. African J. Food Sci., 4(1): 016-025.

Hernandez-Balada, E.M.M., Taylor, J.G. Phillips, W.N. Marmer and E.M. Brown. 2009. Properties of Biopolymers Produced by Transglutaminase Treatment of Whey Protein Isolate and Gelatin. J. Biores. Technol., 100: 36383643.

Koocheki, A., Kadkhodaee, R. 2009. Effect of Alyssum homolocarpum Seed Gum, 
Tween 80 and $\mathrm{NaCl}$ on Droplets Characteistics, Flow Properties and Physical Stability of Ultrasonically Prepared Corn Oil-in-Water Emulsion. Food Hydrocolloids, 25: 1149-1157.

Korhonen, H. 2009. Milk-derived bioactive peptides: From science to applications. J. Func. Foods S1, 177-187.

Liang, C., Li, Do., Wan, G., Xu, J and Hou, W. 2001. Facile synthesis of concentrated gold nanoparticles with low size-distribution in water: temperature and $\mathrm{pH}$ controls, Nano. Res. Lett., 6: 1-10.

Li, Junwen, Tiejing Li and Xinhuai Zhao. 2009. Hydrogen peroxide and ferulic acid-mediated oxidative crosslinking of casein catalyzed by horseradish peroxidase and the impacts on emulsifying property and microstructure of acidified gel. African J. Biotechnol., 8(24): 6993-6999.

Morshed, M.A. 2011. In vitro antimicrobial and cytotoxixity screening of terminalin arjuna ethanol extract, Int. J. Biosci., 1: 31-38.

Rahayu, P.P, Purwadi, Radiati, Manab. 2015. Physico Chemical Properties of Whey Protein and Gelatine Biopolymer Using Tea Leaf Extract as Crosslink Materials. Curr. Res. Nutri. Food Sci., Vol. 3(3), 224-236.

Rhoades, Roller. 2000. Antimicrobial actions of degraded and native chitosan against spoilage organisms in laboratory media and foods. Appl. Environ. Microbiol., 66(1): 80-86.
Sobral, P.J.A., A.M.Q.B. Habitante. 2001. Phase Transitions of Pigskin Gelatin. Food Hydrocolloids, 15: 377-382.

Strauss, G., S.M. Gibson. 2004. Plant Phenolics as Cross-linkers of Gelatin Gels and Gelatin-based Coacervates for Use as Food Ingredients, J. Food Hydrocolloids, 18: 81-89.

Suwetja, I.K. 2007. Biochemistry fisheries. Volumes III. Rigormortis, TMAO and ATP. The faculty of fisheries and oceanography. Sam Ratulangi University Manado.

Thaiudom Siwatt, Kallaya Khantarat. 2011. Stability and rheological properties of fat-reduced mayonnaise by using sodium octenyl succinate starch as fat replacer. Procedia Food Sci., 1: 315321.

Tamura, H., Y. Tsuruta and S. Tokura. 2002. Preparation of chitosan-coated alginate filament. Materials Sci. Engi., 20: 143147.

Tang, Z.X., L.E. Shi, and J.Q. Qian. 2007. Neutral lipase from aqueous solutions on chitosan nano-particles. Biochem. Engi. J., 34 : 217-223.

Wu, S., Jiang, W., sun, Z., Dai, J., Liu, L., Li, F. 2013. Preparation of Magnetic Fluorescent Nanospheres by Sonochemical Method, J. Magnetism and Magnetic Mater., 323: 2170-2173

Zheng and Jiang. 2014. Emulsifying and Foaming Properties of Soy Protein Isolates with Covalent Modification by (-)-Epigallocatechin-3-Gallate. J. Food Sci. Tech., 6: 238-240.

\section{How to cite this article:}

Novia Wahyuana Triawati, Lilik Eka Radiati, Imam Thohari and Abdul Manab. 2016. Microbiological and Physicochemical Properties of Mayonnaise Using Biopolymer of Whey Protein-Gelatin-Chitosan during Storage. Int.J.Curr.Microbiol.App.Sci. 5(7): 191-199. doi: http://dx.doi.org/10.20546/ijcmas.2016.507.019 